\title{
LEÔNIDAS BRAGA DIAS
}

A 4 de abril de 2002, faleceu repentinamente em Belém, Pará, o cientista, professor, historiador, escritor, poeta e pintor Dr. Leônidas Braga Dias. Pioneiro nas pesquisas sobre a hepatologia e Histopatologia dos arbovírus na Amazônia Brasileira a sua história mostra uma personalidade compromissada com a realidade em sua volta e uma busca contínua do conhecimento.

Nasceu em Guajará- Mirim, atual Estado de Rondônia em 1928, onde iniciou sua formação, continuando-a em Manaus, Amazonas, prosseguindo em Belém, Pará, na qual, em 1953 graduou-se em Medicina pela Faculdade de Medicina e Cirurgia do Pará, atualmente fazendo parte da Universidade Federal desse Estado. Ainda no curso de graduação já manifestara interesse pela Anatomia Patológica motivando-o a deslocar-se para S. Paulo, três meses após a sua graduação. Nessa cidade, inicia estágio nesta especialidade como médico residente do Hospital Antônio Cândido Camargo da Associação Paulista de Combate ao Câncer (atual Fundação Antônio Prudente). No ano seguinte transferiu-se para o Hospital dos Servidores do Estado (HSE/IPASE- Instituto de Previdência e Assistência dos Servidores do Estado) como médico, a principio, interino, depois efetivado por concurso (1956) como médico especialista em Anatomia Patológica (em segundo lugar). No ano seguinte assume o cargo de chefe de Clínica, eventual, do Serviço referente a esta especialidade desse hospital, função que exerceu até 1962. É no HSE que iniciou suas atividades como pesquisador em colaboração entre outros com Domingos De Paola, colaboração esta que

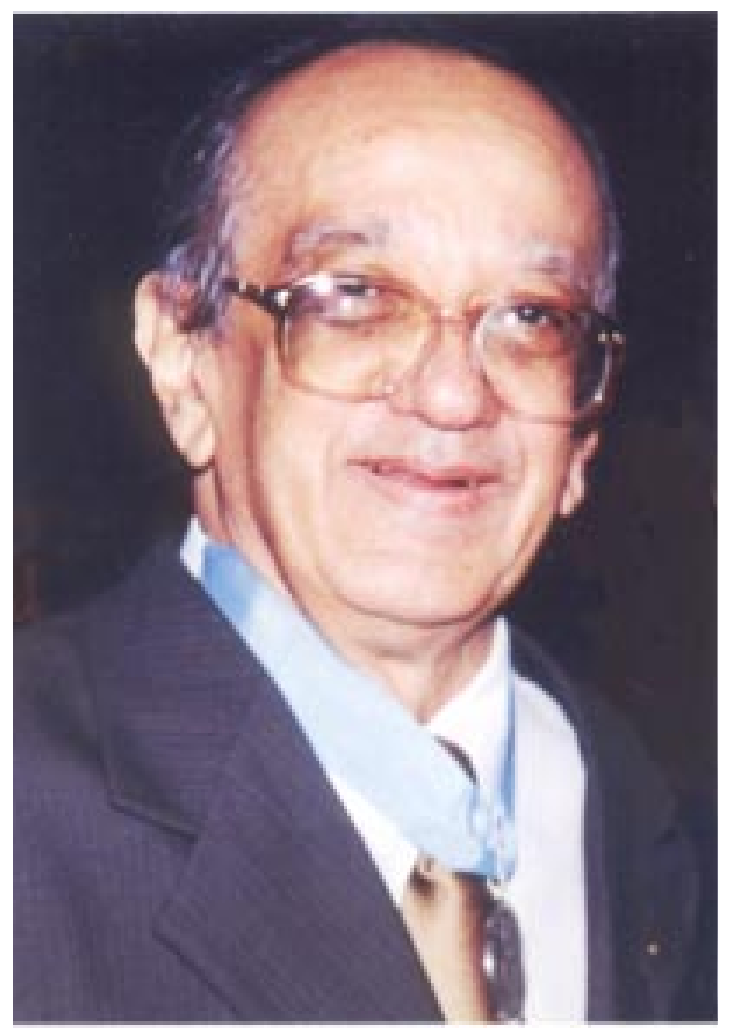
teve profunda repercussão em seu futuro trabalho como pesquisador. É neste período que, também, desenvolveu intensas atividades didáticas: Assistente Voluntário, Professor Assistente da Faculdade Nacional de Medicina da Universidade do Brasil; Professor Auxiliar, Professor Colaborador e Professor Associado, do Instituto de Aperfeiçoamento Médico( Escola Médica de Pós- Graduação) da Pontifícia Universidade Católica do Rio de Janeiro. Retornando a Belém, em 1964, assim que os compromissos assumidos o permitiram retorna ás atividades docentes, como Professor Assistente, disciplina de Histologia e Embriologia e a partir de 1971 da disciplina de Anatomia e Fisiologia Patológicas, do Centro de Ciências Biológicas da Universidade Federal do Pará.

Em Belém continuou as suas atividades de pesquisa no Instituto Evandro Chagas/Fundação Serviços de Saúde Pública( IEC/FSESP) entre outros motivos pelo trabalho colaborativo com Domingos De Paola e Manuel Bruno Lobo, ex-Diretor dessa Instituição (1961-63). Com o apoio de Orlando Costa, então diretor do Instituto Evandro Chagas(IEC/FSESP), e sua incorporação ao grupo de pesquisadores dessa Instituição em 1964, participou da criação e implantação da Seção de Patologia, sendo designado chefe da mesma, como contratado. A partir de 09/06/1965 passou a pertencer ao quadro da FSESP como médico e chefe da Seção criada no ano anterior.

Nesta condições, retomando os estudos de Domingos de Paola, iniciou a sua contribuição à histopatologia das infeções pelos arbovírus onde avultaram os trabalhos no âmbito experimental, contribuição esta que pode ser considerada como a mais abrangente e referência obrigatória dos estudiosos de arboviroses.

Ainda no IEC, entre outras importantes participações, destacam-se as voltadas para a Hepatologia Tropical. Neste âmbito foi pioneiro ao propor, associado a Mário Moraes, a denominação de hepatite de Labrea para o quadro histopatológico típico que eles caracterizaram como uma entidade clínico-patológica distinta, cujo o agente causal provavelmente um vírus deveria ser pesquisado o que verdadeiramente ocorreu nas décadas seguintes, com sua permanente colaboração. O quadro histopatológico típico de Leônidas Dias e Mário Morais só foi reconhecido pelos autores americanos em 1976 quando Afonso Strano colocou a hepatite de Labrea como uma entidade clínica autônoma, no livro Pathology of Tropical and Extraordinary Diseases publicado em 1976.

Além do pioneirismo as observações de Leônidas e Moares desencadearam interesse não só nacional como internacional. No próprio IEC motivou a criação de novas linhas de pesquisas introdução de novas tecnologias de laboratório como de investigação de campo: a criação de um município sentinela. 
Apesar de ter-se desligado oficialmente do IEC em 31.12.70, na verdade Leônidas sempre participou das atividades do IEC ligadas aos assuntos que lhe eram caros: arboviroses e hepatites por vírus. Deixa nesta área uma centena de trabalhos publicados quer como artigos ou capítulos de livro.

Como pesquisador a sua curiosidade e sensibilidade não ficaram restritas ao âmbito médico. Preocupava-o a falta do registro, da memória do exercício da medicina na Região Norte e, em particular no Estado do Pará. Dedicou-se então a História da Medicina motivo pelo qual foi empossado como sócio do Instituto Histórico e Geográfico do Pará tendo sido empossado. Foi sóciofundador da Academia de Medicina do Pará ocupando a cadeira No 29 e seu vice-presidente no Biênio 1995/ 96 e ainda tomando parte no Conselho de editoração dos Anais. Fazia parte do Conselho Editorial da Revista
Paraense de Medicina. Como historiador, atividade a que se dedicou nos últimos 10 anos de sua vida deixa cerca de uma dezena de trabalhos publicados.

A sensibilidade e capacidade de reflexão manifestaram também como poeta e pintor. A sua faceta de poeta só dada a conhecer nos últimos cinco anos como a de pintor tem muito a ver com a sua qualidade de cientista. A de poeta revelando aspectos de sua infância e as qualidades e os sonhos da criança que conservou pela vida afora e que o ajudaram a ser o cientista que foi: conservei a curiosidade do menino transformando-a numa permanente busca do conhecimento. A de pintor, pelo deslumbramento que as cores de suas laminas the proporcionavam.

Deixa esposa e cinco filhos dentre os quais dois médicos um dos quais tem o seu nome e segue sua especialidade.

Gilberta Bensabath 